\title{
Range extension and natural history comments of periurban populations of Sphaenorhynchus caramaschii Toledo, Garcia, Lingnau \& Haddad, 2007 (Anura, Hylidae) in the state of São Paulo, Brazil
}

\author{
Marcos Antônio Melo ${ }^{1,2}$, Kleber Evangelista Rodrigues ${ }^{3}$, Sostenes José Souza Pelegrini ${ }^{4}$, \\ Renato Augusto Martins ${ }^{5}$
}

1 Divisão Técnica de Medicina Veterinária e Manejo da Fauna Silvestre, Secretaria do Verde e do Meio Ambiente do Município de São Paulo. Avenida IV Centenário, 1268, Parque Ibirapuera, Portão 7A, CEP 04030-000, São Paulo, SP, Brazil. 2 Current address: Programa de Pós-Graduação em Ecologia e Recursos Naturais, Universidade Federal de São Carlos, Rod. Washington Luís, km 235, 13565-905, São Carlos, SP, Brazil. 3 Autonomous Researcher. R. Aurora de Jesus, 178, 06900-000, Embu-Guaçu, SP, Brazil. 4 JGP Consultoria e Participações Ltda. R. Américo Brasiliense, 615, Alto da Boa Vista, 04715-000, São Paulo, SP, Brazil. 5 Programa de Pós-Graduação em Conservação de Fauna, Universidade Federal de São Carlos, Centro de Ciências Biológicas e da Saúde, Rodovia Washington Luiz, km 235, Jardim Guanabara, 13565-905, São Carlos, SP, Brazil.

Corresponding author: Marcos Antônio Melo,mam_melo@yahoo.com.br

\begin{abstract}
The present study records the occurrence of Sphaenorhynchus caramaschii Toledo, Garcia, Lingnau \& Haddad, 2007 for periurban areas of São Paulo and Sorocaba cities, eastern side of São Paulo state. These new records represent the northeastern known localities for this species and expand the septentrional limit of its geographic distribution. We also present comments and biological information for these recently discovered populations.
\end{abstract}

\section{Key words}

Amphibia; Neotropical treefrog; Atlantic Forest; São Paulo; range expansion.

Academic editor: Natan Medeiros Maciel | Received 26 April 2018 | Accepted 16 August 2018 | Published 21 September 2018

Citation: Melo MA, Rodrigues KE, Pelegrini SJS, Martins RA (2018) Range extension and natural history comments of periurban populations of Sphaenorhynchus caramaschii Toledo, Garcia, Lingnau \& Haddad, 2007 (Anura, Hylidae) in the state of São Paulo, Brazil. Check List 14 (5): 779-783. https://doi.org/10.15560/14.5.779

\section{Introduction}

Recent studies have discovered new species of Sphaenorhynchus genus (Toledo et al. 2007, Caramaschi et al. 2009, Araujo-Vieira et al. 2015, Roberto et al. 2017), which currently consists of 15 species of small greenish tree frogs (Frost 2018). These species inhabit permanent and temporary ponds in open areas and forest edges, with floating vegetation or partially submerged in the water (e.g., Lutz and Lutz 1938, Bokermann 1973, Cruz and Peixoto 1980).

Most species of Sphaenorhynchus are widespread throughout in the Brazilian Atlantic Forest, from the state of Pernambuco to Rio Grande do Sul (e.g. Cochran 1953, Bokermann 1973, Caramaschi et al. 2009, Araujo-Vieira et al. 2015, Roberto et al. 2017), but only S. platycephalus (Werner, 1894) (see Araujo-Vieira et al. 2018) and $S$. caramaschii have been recorded in the state of São Paulo 

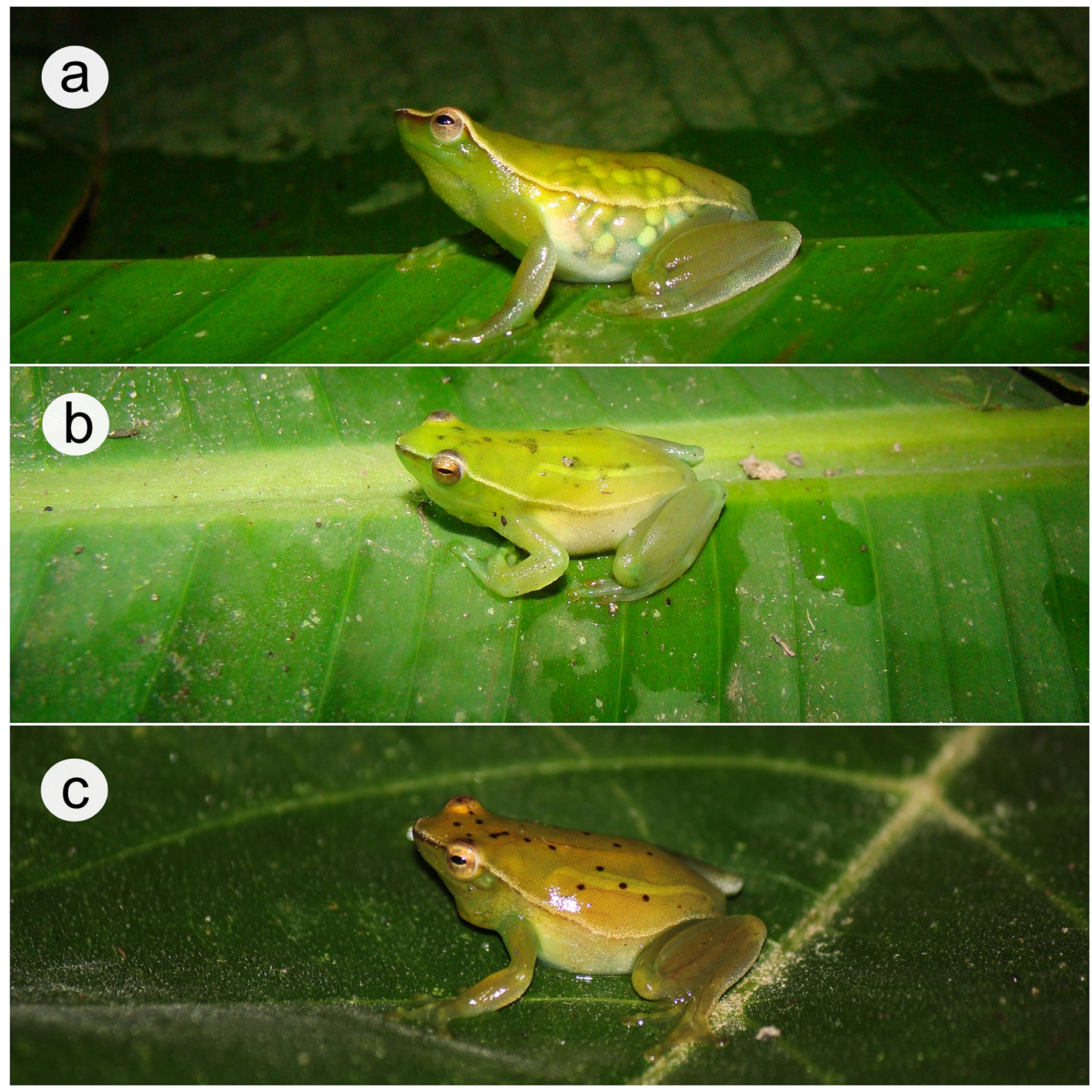

Figure 1. Live specimens photographed: a) female with visible eggs in Parque Natural Municipal Cratera Colonia, São Paulo, SP; b) male in Fazenda Castanheiras, São Paulo, SP (ZUEC-AMP 18211); and c) male in the district of Marmeleiro, Mairinque, SP.

\section{(Rossa-Feres et al. 2011).}

Sphaenorhynchus caramaschii Toledo, Lingnau, Garcia \& Haddad, 2007 is a medium-sized species within the genus (snout-vent length: $23.25-25.94 \mathrm{~mm}$ in males and $26.45-28.89 \mathrm{~mm}$ in females). This species presents a lengthy advertisement call (Toledo et al. 2007), which contains a long note with evident pulses and a short note with one pulse (Forti et al. 2017). During rainy season, males vocalize mainly perched on the emergent plants at ponds in open areas and forest edges (Toledo et al. 2007, Almeida et al. 2008, Forti et al. 2017). The eggs are attached individually to submerged vegetation. Sphaenorhynchus caramaschii occurs at the highlands of the states of Santa Catarina, Paraná and São Paulo, Brazil (Toledo et al. 2007). In the state of São Paulo, this species is distributed in the southern and central portions, noticeably in the municipalities of Botucatu and Pilar do Sul, that represent, respectively, north and northeastern limits of its geographical distribution (Toledo et al. 2007, Almeida et al. 2008). The present study shows new records of $S$. caramaschii and expands the northeastern limit of its geographic distribution and also presents comments on the natural history of these populations.

\section{Methods}

Between the years 2011 and 2013, individuals of Sphaenorhynchus caramaschii were recorded in various sites in the state of São Paulo, Brazil (see Table 1 for sources including the present study). The calls of the males were recorded using a digital recorder (Marantz PMD 660) and an external directional microphone (Seinheiser ME 66) and photographed with a digital camera (Sony DSC-H9). Advertisement calls were deposited 
Table 1. Records of Sphaenorhynchus caramaschii in the state of São Paulo.

\begin{tabular}{|c|c|c|c|c|c|}
\hline Site & Municipality & Latitude (S) & Longitude (W) & Altitude (m) & Source \\
\hline $\begin{array}{l}\text { Parque Natural Municipal Cratera } \\
\text { do Colônia }\end{array}$ & São Paulo & $23^{\circ} 52^{\prime} 54^{\prime \prime}$ & $046^{\circ} 42^{\prime} 37^{\prime \prime}$ & 760 & Present study \\
\hline Fazenda Castanheiras & São Paulo & $23^{\circ} 49^{\prime} 22^{\prime \prime}$ & $046^{\circ} 38^{\prime} 53^{\prime \prime}$ & 750 & Present study \\
\hline Parque da Várzea do Embu-Mirim & Embu das Artes & $23^{\circ} 39^{\prime} 48^{\prime \prime}$ & $046^{\circ} 49^{\prime} 31^{\prime \prime}$ & 770 & Present study \\
\hline Marmeleiro & Mairinque & $23^{\circ} 32^{\prime} 15^{\prime \prime}$ & $047^{\circ} 09^{\prime} 47^{\prime \prime}$ & 820 & Present study \\
\hline Floresta Nacional de Ipanema & Iperó & $23^{\circ} 25^{\prime} 49^{\prime \prime}$ & $047^{\circ} 38^{\prime} 03^{\prime \prime}$ & 700 & Present study \\
\hline Not available & Tapiraí & $23^{\circ} 55^{\prime} 06^{\prime \prime}$ & $047^{\circ} 28^{\prime} 07^{\prime \prime}$ & 870 & Condez et al. 2009 \\
\hline Rio do Peixe & Ibiuna & $23^{\circ} 52^{\prime} 53^{\prime \prime}$ & $047^{\circ} 21^{\prime} 29^{\prime \prime}$ & 860 & Araujo et al. 2013 \\
\hline Not available & Pilar do Sul & $23^{\circ} 48^{\prime} 46^{\prime \prime}$ & $047^{\circ} 43^{\prime} 27^{\prime \prime}$ & 700 & Toledo et al. 2007 \\
\hline $\begin{array}{l}\text { Parque Estadual Estância Turistica do } \\
\text { Alto do Ribeira }\end{array}$ & Iporanga & $24^{\circ} 25^{\prime} 01^{\prime \prime}$ & $048^{\circ} 29^{\prime} 59^{\prime \prime}$ & 270 & Toledo et al. 2007 \\
\hline Not available & Apiaí & $24^{\circ} 30^{\prime} 40^{\prime \prime}$ & $048^{\circ} 50^{\prime} 47^{\prime \prime}$ & 260 & Toledo et al. 2007 \\
\hline Fazenda Intermontes & Ribeirão Grande & $24^{\circ} 11^{\prime} 45^{\prime \prime}$ & $048^{\circ} 25^{\prime} 29^{\prime \prime}$ & 950 & Toledo et al. 2007 \\
\hline Fazenda São Luis & Ribeirão Branco* & $24^{\circ} 21^{\prime} 30^{\prime \prime}$ & $048^{\circ} 44^{\prime} 35^{\prime \prime}$ & 910 & Toledo et al. 2007 \\
\hline Fazenda Intermontes & Ribeirão Grande & $24^{\circ} 11^{\prime} 58^{\prime \prime}$ & $048^{\circ} 26^{\prime} 08^{\prime \prime}$ & 905 & Araujo-Vieira et al. 2015 \\
\hline Estação Ecológica Angatuba & Guareí & $23^{\circ} 26^{\prime} 04^{\prime \prime}$ & $048^{\circ} 19^{\prime} 53^{\prime \prime}$ & 740 & Araujo \& Santos-Almeida 2013 \\
\hline Estação Ecológica Angatuba & Guareí & $23^{\circ} 25^{\prime} 16^{\prime \prime}$ & $048^{\circ} 19^{\prime} 10^{\prime \prime}$ & 720 & Araujo \& Santos-Almeida 2013 \\
\hline Estação Ecológica Angatuba & Angatuba & $23^{\circ} 25^{\prime} 40^{\prime \prime}$ & $048^{\circ} 21^{\prime} 25^{\prime \prime}$ & 645 & Araujo \& Santos-Almeida 2013 \\
\hline Not available & Avaré & $22^{\circ} 51^{\prime} 09^{\prime \prime}$ & $048^{\circ} 50^{\prime} 11^{\prime \prime}$ & 600 & Almeida et al. 2008 \\
\hline Rubião Junior & Botucatu & $22^{\circ} 51^{\prime} 55^{\prime \prime}$ & $048^{\circ} 32^{\prime} 59^{\prime \prime}$ & 835 & Almeida et al. 2008 \\
\hline Rubião Junior & Botucatu & $22^{\circ} 59^{\prime} 36^{\prime \prime}$ & $048^{\circ} 29^{\prime} 31^{\prime \prime}$ & 824 & Almeida et al. 2008 \\
\hline Fazenda Rio Claro & Lençóis Paulista & $22^{\circ} 46^{\prime} 55^{\prime \prime}$ & $048^{\circ} 50^{\prime} 46^{\prime \prime}$ & 610 & Almeida et al. 2008 \\
\hline
\end{tabular}

in the Fonoteca Neotropical Jacques Vielliard (FNJV), Universidade Estadual de Campinas (UNICAMP). Specimens were euthanized via anesthetic overdose $(5 \%$ lidocaine), fixed in $10 \%$ formalin, and preserved in $70 \%$ ethyl alcohol. We collected (collection permit \#14/2012 Proc. SMA/CFS 8.431/2011) 2 males in the municipality of Embu das Artes and the amphibians were deposited in the Museu de Zoologia da Universidade de São Paulo (MZUSP), and another specimen was collected in the municipality of São Paulo and deposited in the Museu de História Natural (ZUEC), UNICAMP.

\section{Results}

New records. Brazil: São Paulo. Municipality of São Paulo. Near the Parque Natural Municipal da Cratera de Colônia, PNMCC (2352'54" S, 04642'37" W, WGS84 datum, $760 \mathrm{~m}$ elev.), Marcos A. Melo and Kleber E. Rodrigues observers/collectors, 9 October 2011 (1 female with visible eggs, photographed, Fig. 1a, not collected; advertisement calls from 1 male, FNJV 12045 and the specimen collected, ZUEC-AMP 18211. Municipality of São Paulo: Fazenda Castanheiras, in the Environmental Protection Area (EPA) Bororé-Colônia, in a branch of the Billings reservoir $\left(23^{\circ} 49^{\prime} 22^{\prime \prime} \mathrm{S}, 046^{\circ} 38^{\prime} 53^{\prime \prime} \mathrm{W}\right.$, WGS84 datum, $750 \mathrm{~m}$ elev.), Marcos A. Melo and Kleber E. Rodrigues observers, 18 September 2011 (1 adult male photographed, Fig. 1b, not collected). Municipality of Embu das Artes: Parque da Várzea do Embu-Mirim, in a permanent pond $\left(23^{\circ} 39^{\prime} 48^{\prime \prime} \mathrm{S}, 046^{\circ} 49^{\prime} 31^{\prime \prime} \mathrm{W}, 770 \mathrm{~m}\right.$ elev.), Renato A. Martins and Sostenes J. S. Pelegrini collectors, March and August 2012 (2 specimens, MZUSP 150397 and MZUSP 150398). Municipality of Mairinque:

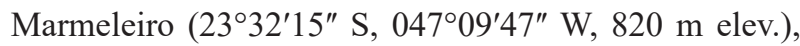

Sostenes J. S. Pelegrini and Marcos A. Melo observers, 29 August 2013 (1 specimen, photographed, Fig. 1c). Municipality of Iperó: Floresta Nacional de Ipanema, in a permanent pond $\left(23^{\circ} 25^{\prime} 49^{\prime \prime} \mathrm{S}, 047^{\circ} 38^{\prime} 03^{\prime \prime} \mathrm{W}, 700 \mathrm{~m}\right.$ elev.), Kleber E. Rodrigues recorder, 4 November 2012 (advertisement calls, FNJV0037786).

Identification. Specimens were found to be in agreement with the description in Toledo et al. (2007), following the feature combination that distinguishes Sphaenorhynchus caramaschii from others species within the genus, such as 1) absence of external tympanum, 2) presence of a dark line from the snout to the eyes, and especially 3 ) by the long and remarkable advertisement call (Toledo et al.2007, Forti et al. 2017). This species is morphologically similar to $S$. surdus and distinguished by its snout generally truncated; its head can be slightly mucronated and, its advertisement call is especially long (Toledo et al. 2007). This advertisement call can last 11.5 seconds and can reach 1-43 notes, which can be long multipulsed and/or short single pulse (Forti et al. 2017). This identification was confirmed by Prof. Dr Felipe Toledo, one of the researchers that described the species (Toledo et al. 2007).

\section{Discussion}

The distribution of Sphaenorhynchus caramaschii had little changes since the last range expansion (Almeida et al. 2008). Some new records were added, but they are among expected localities and same hydrographical basin. For example, records of this species in Tapiraí (Condez et al. 2009) and between Ibiúna/Piedade (Araujo et al. 2013) are 31 and $36 \mathrm{~km}$ distant from Pilar do Sul 


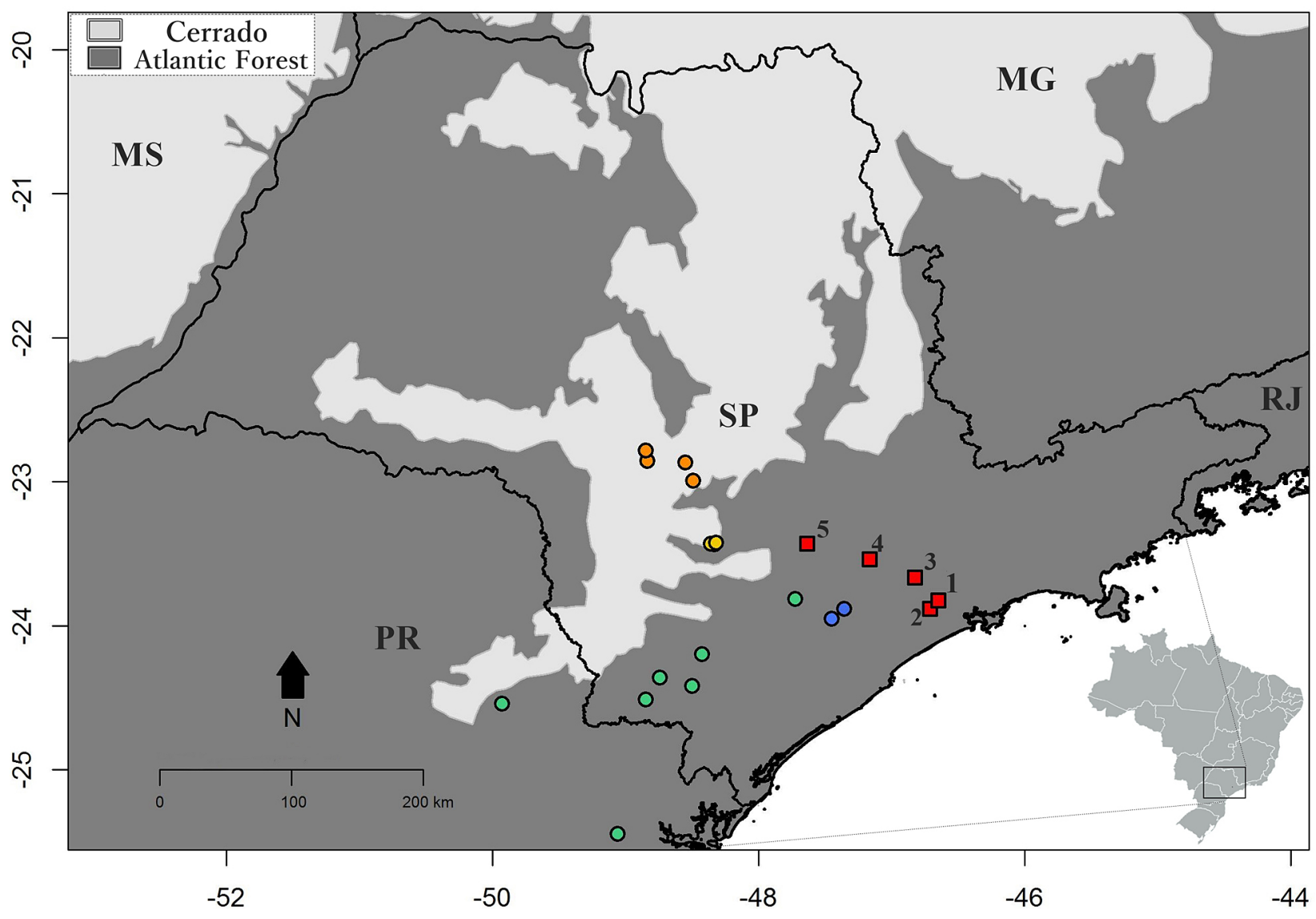

Figure 2. Distribution map of Sphaenorhynchus caramaschii. Previous records in the last review by Almeida et al. (2008): green circles (Toledo et al. 2007), orange circles (Almeida et al. 2008); Update review: yellow circles (Araujo and Santos-Almeida 2013), blue circles (Condez et al. 2009, Araujo et al. 2013); This study: red squares: new records in the municipalities of São Paulo'-2, Embu das Artes ${ }^{3}$, Mairinque ${ }^{4}$ and Iperó5 .

(Toledo et al. 2007), respectively; records in Angatuba and Guareí (Araujo and Almeida-Santos 2013) are 60 and $65 \mathrm{~km}$ from Botucatu (Almeida et al. 2008), respectively. These records were expected because they were among the municipalities of Pilar do Sul and Botucatu and they do not provide substantial changes of the species distribution limits.

Herein, we present 5 new records of $S$. caramaschii in the state of São Paulo, Brazil (Fig. 2). Our first records from municipality of São Paulo extend the geographic distribution of $S$. caramaschii in Alto Tietê basin and extending the range by approximately $70 \mathrm{~km}$ on the northeastern side from Piedade/Ibiúna (Araujo et al. 2013), and $200 \mathrm{~km}$ east from Botucatu (Almeida et al. 2008). Moreover, we present the first records of this species in municipalities of Embu das Artes, Mairinque, and Iperó, filling the gap among the previous studies (Toledo et al. 2007, Almeida et al. 2008) and municipality of São Paulo (Fig. 2).

The vegetal formation in the new localities is composed by Dense Ombrophilous Forest, except in Iperó that presents Seasonal Semidecidual Forest. In the Brazilian Savanna (Cerrado) of the state of São Paulo, the species has already been recorded in Seasonal Semidecidual Forest (Almeida et al. 2008), representing the unique records outside Atlantic Forest. All permanent ponds presented riparian forest in initial stage of regen- eration and abundant floating macrophytes (Salvinia sp.). In Parque Natural Municipal da Cratera de Colônia (PNMCC), most of the males $(n=12)$ were calling on the floating macrophytes, while only 1 specimen was perched on marginal vegetation (Hedychium sp.), confirming the kinds of calling sites described by Toledo et al. (2007). Almeida et al. (2008) suggest that $S$. caramaschii inhabits permanent ponds near the forests. Our observations support this suggestion, although riparian vegetation of Fazenda Castanheiras (FC) is represented mostly by exotic plants Pinnus, Cunninghamia and Eucalyptus.

On these localities, alien species of fish Cyprinus carpio Linnaeus, 1758, Oreochromis niloticus (Linnaeus, 1758) and Tilapia sp. (Mattox 2008), American Bullfrog Lithobathes catesbeianus (Shaw, 1802) (Malagoli 2008), and Crawfish Procambarus clarkii (Girard, 1852) (pers. obs.) embody the local fauna, especially in $\mathrm{FC}$, at the margin of the Billings reservoir. These species are acknowledged as predators of Brazilian anurans in different stages of life and may negatively impact its populations (Leivas et al. 2012, Banci et al. 2013). Besides, these new records are next $($ mean $=4.6 \mathrm{~km}, \min =0.1, \max .=16, n=5)$ to the fringe of metropolitan areas (São Paulo and Sorocaba). The expansion of urban areas over natural habitats has caused the dramatical impoverishment of the high diversity of Atlantic Forest anuran assemblages (Lourenço-de-Moraes et al. 2018). Although S. caramaschii populations present 
the ability of adjustment to landscape changes (Toledo et al. 2007), the reason of its persistence in the urban landscape is not clear and needs long-term monitoring.

\section{Acknowledgements}

We are grateful to Felipe Toledo who confirmed our identification of the species, to André Assalim and the wildlife management professionals of DEPAVE-3 for their support and field contributions, to Selma Godoy and Ingrid Scheeffer for translating the text, to Heidi Cristina Martins França de Oliveira for the English review, and to the 2 reviewers and the academic editor for helpful comments on this manuscript.

\section{Authors' Contributions}

MAM and RAM wrote the manuscript with support from SJSP and KER. All authors collected data and identified the specimens, as well as discussed the results and contributed to the final manuscript.

\section{References}

Almeida SC, Maffei F, Rolim DC, Ubaid FK, Jim J (2008) Amphibia, Anura, Hylidae, Sphaenorhynchus caramaschii: Distribution extension in state of São Paulo, Brazil. Check List 4 (4): 439-441. https://doi.org/10.15560/4.4.439

Araujo CO, Almeida-Santos SM (2013) Composição, riqueza e abundância de anuros em um remanescente de Cerrado e Mata Atlântica no estado de São Paulo. Biota Neotropica 13 (1): 265-275.

Araujo CO, Matsukuma CK, Almeida-Santos SM (2013) Taxonomic composition and distribution of anurans in the Upper and Middle Paranapanema, São Paulo state, Brazil. Biota Neotropica 13 (3): 241-258.

Araujo-Vieira K, Lacerda JVA, Pezzuti TL, Leite FS, Assis CL, Cruz CAG (2015) A new species of hatchet-faced treefrog Sphaenorhynchus Tschudi (Anura: Hylidae) from Quadrilátero Ferrífero, Minas Gerais, southeastern Brazil. Zootaxa 4059: 96-114. https://doi. org/10.11646/zootaxa.4059.1.5

Araujo-Vieira K, Caramaschi U, Grillittsch H, Grant T, Faivovich J (2018) On the identity of Sphaenorhynchus platycephalus (Werner, 1984) (Anura:Hylidae). South American Journal of Herpetology 13 (1): 73-84. https://doi.org/10.2994/SAJH-D-17-00053.1

Banci KRS, Viera NFT, Marinho PS, Calixto PO, Marques OAV (2013) Predation of Rhinella ornata (Anura, Bufonidae) by the alien crayfish (Crustacea, Astacidae) Procambarus clarkii (Girard, 1852) in São Paulo, Brazil. Herpetology Notes 6: 339-341.

Bokermann WCA (1973) Duas novas espécies de Sphaenorhynchus da
Bahia (Anura, Hylidae). Revista Brasileira de Biologia 33: 589-594. Caramaschi U, Almeida AP, Gasparini JL (2009). Description of two new species of Sphaenorhynchus (Anura, Hylidae) from the State of Espírito Santo, southeastern Brazil. Zootaxa 2115: 34-46. https://doi.org/10.5281/zenodo. 187954

Cochran DM (1953) Three new Brazilian frogs. Herpetologica 8: 111-115.

Condez TH, Sawaya RJ, Dixo M (2009) Herpetofauna dos remanescentes de Mata Atlântica da região de Tapiraí e Piedade, SP, sudeste do Brasil. Biota Neotropica 9 (1): 157-185.

Cruz CAG, Peixoto OL (1980) Notas sobre o girino de Sphaenorhynchus orophilus (Lutz \& Lutz, 1938) (Amphibia, Anura, Hylidae). Revista Brasileira de Biologia 40: 383-386.

Forti LR, Lingnau R, Bertoluci J (2017) Acoustic variation in the advertisement call of the Lime treefrog Sphaenorhynchus caramaschii (Anura: Hylidae). Vertebrate Zoology 67: 197-205.

Frost DR (2018) Amphibians Species of the World: an Online Reference. Version 6.0. American Museum of Natural History, New York. https://research.amnh.org/herpetology/amphibia/index.html. Accessed on: 2018-3-29.

Leivas PT, Leivas FWT, Moura MO (2012) Diet and trophic niche of Lithobates catesbeianus (Amphibia: Anura). Zoologia 29: 405412. https:// doi.org/10.1590/S1984-46702012000500003

Lourenço-de-Moraes R, Malagoli LR, Guerra V, Ferreira RB, Affonso IP, Haddad CFB, Sawaya RJ, Bastos RP (2018) Nesting patterns among Neotropical species assemblages: can reserves in urban areas be failing to protect anurans? Urban Ecosystems 21: 1-10. https://oi.org/10.1007/s11252-018-0767-5

Lutz A, Lutz B (1938) I. On Hyla aurantiaca Daudin and Sphoenorhynchus Tschudi and on two allied Hylae from south-eastern Brasil. II. Two new hylae, H. albosignata sp. nov. \& H. picheli. Anais da Academia Brasileira de Ciências 10: 175-194.

Malagoli LR (2008) Anfíbios do município de São Paulo: histórico, conhecimento atual e desafios para a conservação. In: Malagoli LR, Bajesteiro FB, Whately M (Eds). Além do concreto: contribuições para a proteção da biodiversidade paulistana. Instituto Sócio Ambiental, São Paulo, 204-233.

Mattox GMT (2008) Peixes do município de São Paulo: passado, presente e future. In: Malagoli LR, Bajesteiro FB, Whately M (Eds). Além do concreto: contribuições para a proteção da biodiversidade paulistana. Instituto Sócio Ambiental, São Paulo, 180-203.

Roberto IJ, Araujo-Vieira K, Carvalho-e-Silva SP, Ávila RW (2017) A new species of Sphaenorhynchus (Anura: Hylidae) from northeastern Brazil. Herpetologica 73 (2): 148-161. https://doi.org/10.1655/ herpetologica-d-16-00021

Rossa-Feres DC, Sawaya RJ, Faivovich J, Giovanelli JGR, Brasileiro CA, Schiesari L, Alexandrino J, Haddad CFB (2011) Anfíbios do estado de São Paulo, Brasil: Conhecimento Atual e Perspectivas. Biota Neotropica 11 (1a): 47-66.

Toledo LF, Garcia PCA, Lingnau R, Haddad CFB (2007) A new species of Sphaenorhynchus (Anura; Hylidae) from Brazil. Zootaxa 1658: 57-68. https://doi.org/10.11646/zootaxa.1658.1.4 